\title{
Indices to monitor biological soil crust growth rate-lab and field experiments
}

\author{
Avraham Dody $^{1^{*}}$, Roni Hakmon ${ }^{1}$, Boaz Asaf ${ }^{1}$, Eli Zaady ${ }^{2}$ \\ ${ }^{1}$ Nuclear Research Center-Negev, Beer Sheva, Israel; * corresponding author: dodik@bgu.ac.il \\ ${ }^{2}$ Department of Natural Resources and Agronomy, Gilat Research Center, Israel.
}

Received 28 March 2011; revised 23 April 2011; accepted 8 May 2011.

\begin{abstract}
The aim of this work was to identify test methods for accelerating growth of biological soil crust (BSC). The BSC in the Yamin Plateau in the north-east of the Negev Desert is composed of cyanobacteria such as microcoleus spp. nostoc spp. and others. Cyanobacteria are well adapted to dry environments, owing to their ability to survive desiccation, high temperatures and solar radiation. Since the BSC is a live component in the ecosystem, it can repair itself in the event of failures such as environmental disturbances by living things. In the lab, we used five different treatments and mediums: natural BSC, pure sand as reference, pure sand with spores and propagules, pure sand with whey, and pure sand with spores and propagules and whey. The spores were collected from specified collecting areas in the field. Each Petri dish was irrigated daily with $10 \mathrm{~mL}$ of doubledistilled water. The testing period ran for 4.5 months with 10 samples taken from each treatment at $\mathbf{1 . 5}$ month intervals. The analyses criteria were: NDVI for chlorophyll content by remote sensing techniques, polysaccharide content, infiltration rate through the crust, protein and organic content. The results showed that NDVI, polysaccharides and infiltration rates are good indicators for showing growth acceleration of the crust; while protein and organic content were found to be less indicative. The treatments using whey for preliminary crust failed in the lab since cracks were observed, but succeeded in the field experiments. In the field, we measured only the chlorophyll content with a time interval of $\mathbf{2 0}$ months. The methodology of how to accelerate the growth of BSC was found to be effective.
\end{abstract}

Keywords: Microcoleus Spp; Spores; NDVI; Infiltration Rate, Polysaccharides Content

\section{INTRODUCTION}

The main motivation for this study was to identify how to reduce the migration of contaminants into the biosphere from waste disposal sites (WDS). According to International Atomic Energy Agency recommendations, radioactive (and/or other hazardous materials) WDS should be under institutional control for a period of several hundred years after site closure [1]. After that time, the site should be given back to the public for differing land uses. We are suggesting the use of a biological soil crust (BSC) as a top layer over WDS as soon as possible after site closure for the following reasons: 1) BSC has been shown to reduce water infiltration and, therefore, may reduce the leaching of the contaminants toward groundwater; 2) The BSC, when grown over WDS, may reduce the erosion of the topmost layer, and may also reduce the migration of contaminants into the biosphere; 3) Since the BSC is composed of live organisms that renew themselves, its longevity and durability is much longer and greater than any common geo-textile layer; 4) Since the BSC is composed of live organisms in the natural, dry ecosystem (with the ability to survive desiccation, high temperatures and solar radiation) it has the capability of repairing itself in the case of damage or disturbance; 5) The BSC can survive climate changes.

It must be stated very clearly that the idea of using the BSC is not to replace any other engineered barriers, but as an additional layer that should be applied to the top of the WDS.

In semiarid and arid regions of the world, when landscapes are undisturbed, the soil surface is covered with BSC. The BSC community varies significantly by precipitation regime [2-4]. The BSC cover is characterized by a tightly structured surface and typically varies from $2 \mathrm{~mm}$ thick, relatively homogeneous cyanobacterial crusts, to complex crust composition communities of mosses, lichens, soil algae, fungi and cyanobacteria of about $15 \mathrm{~mm}$ thickness [5,6]. The primary colonizers of the crust community, which are composed of cyanobac- 
teria and soil algae, secrete polysaccharide mucilaginous sheaths on the soil surface that bind together the soil particles [7-9]. Consequently, they play an important role in soil surface stabilization for preventing both wind and water erosion $[10,11]$. In the Negev desert (Israel), the combination of relatively high contents of silt and clay particles and the cyanobacterial exudates change the soil/water regime by affecting runoff, rain interception, water-holding capacity and soil moisture content [12-14]. BSC dramatically influences the runoff yield, mainly in arid and semi arid zones [15].

Field measurements, at several study sites in Israel, showed that BSC decreased water infiltration [16,17], by producing a tough cover-layer on the soil surface [4].

The aim of this work was to find the parameters indicating the growth rate of BSC. In nature, the growth rate of the BSC is very slow (years and more) [18]. For this study, BSC spores and propagules were collected from overland runoff in nearby, naturally undisturbed areas and transferred to the laboratory experiments. The natural conditions of the field study area are: soil $\mathrm{pH}$ around 8 , low rainfall amounts $(80 \mathrm{~mm} / \mathrm{y})$ and high potential evapotranspiration $(2200 \mathrm{~mm} / \mathrm{y})$ are the main reasons that the soil surface is dominated by cyanobacteria $(>80 \%$ of the soil cover).

\section{METHOD AND MATERIALS}

Runoff water containing spores and propagules of the BSC were collected from a specific collecting system built in the field at Yamin Plateau, north-east Negev Desert, Israel. The dominant cyanobacteria in our study area are microcoleus spp. and Nostoc spp.

Pure sand (from 0.3 meter below the soil surface) was collected from the natural, undisturbed nearby area and used as substrate. Five treatments were considered: 1) BSC as reference, 2) Pure sand, 3) Pure sand with spores, 4) Pure sand with whey (whey used as coagulating substance), 5) Pure sand with spores and whey. We worked with five sets of Petri-dishes, each containing 30 dishes and totaling 150 samples; each Petri-dish contained 80 grams of pure sand. Runoff water from nearby natural plots containing BSC spores were used to irrigate treatments 3 to 5 (only once). Then, for the next 4.5 months, each Petri-dish was irrigated every day with $10 \mathrm{ml}$ of double-distilled water (DDW). Analysis samples were taken at intervals of 1.5 months, 3 months and 4.5 months. Similar experiments were run in the field on fifteen separate $2 \times 1 \mathrm{~m}$ sand-dune plots where the crust layer of the soil surface was removed.

Growth rates of the BSC were studied using five different variables: infiltration rate, polysaccharide content, protein, organic content and Normalized Difference Vegetation Index (NDVI) and chlorophyll content. A col- umn of $100 \mathrm{~mm}$ of DDW was placed on each Petri-dish (with 5 holes in the bottom) and the infiltration rates were measured. The polysaccharides were measured with a spectrophotometer (UV-VIS mini-1240 spectrophotometer, Shimadzu), using Anthron reagent and Sulfuric acid [19]. Protein content was measured using the Lowry method [20]. The chlorophyll content was extracted with acetone and quantified [21]. Organic content was measured by washing the sample with $0.1 \mathrm{M}$ of $\mathrm{HCl}$ and 5 hours in a $550^{\circ} \mathrm{C}$ furnace [22]. Vegetation index (VI) was developed during recent decades [23], based on different combinations of the ratio between the R-band (which corresponds to the region of maximum chlorophyll absorption), and the NIR-band (which corresponds to maximum reflectance of incident light by living vegetation). The most widely used index is the NDVI and is defined as:

$$
\mathrm{NDVI}=[\mathrm{NIR}-\mathrm{R}] /[\mathrm{NIR}+\mathrm{R}]
$$

where $\mathrm{R}$ and NIR are the radiance and reflectance, or at least "apparent reflectance" in the R and the NIR spectral bands, respectively [24]. The NDVI values lie in the range -1.0 to +1.0 , with denser and/or healthier vegetation having higher positive values.

As mentioned above, we sprayed whey on two treatments. Whey is a byproduct of the cheese- and casein-manufacturing industry [25]. There is continuing interest in utilizing this byproduct as a fermentation substrate for the production of value-added products. In order to check its feasibility to create crust in a short time, we also wanted to study if there was any interrelationship between spores and whey, and how growth rate may be affected.

Data were processed using analysis of variance with the ANOVA statistical package. One-way ANOVA, with Tukey Test's [26] were used to test the differences between treatments (crust-control, sand, sand with spores and sand with spores and whey). The dependent variables were: infiltration rate, polysaccharide content, protein, organic content and NDVI for chlorophyll content. Differences were considered statistically significant if $\mathrm{p}<0.05$.

\section{RESULTS}

The analyses for all treatments were made via the time sequence sets presented in the following figures.

1) Polysaccharides

In all five treatments, the concentrations of the polysaccharides became higher with time (Figure 1). Changes are almost linear in all treatments, but with different rate. The highest value of polysaccharides was found in the whey treatments, and the lowest value in the sand treatment. The relative highest change was found in 


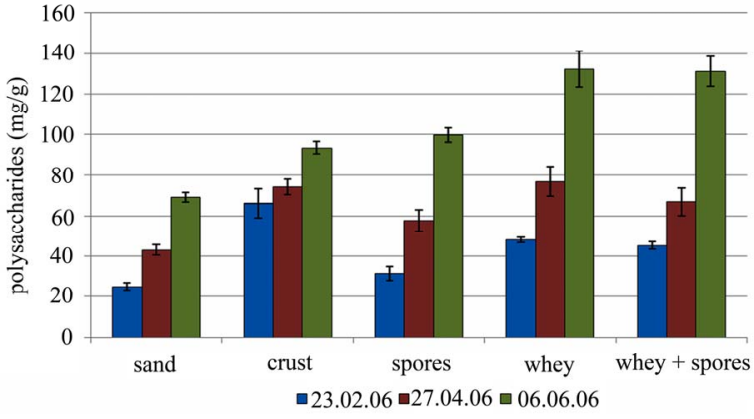

Figure 1. Polysaccharide content with time. The bars indicate the \pm SE.

the spores' treatment from 31 to $100 \mathrm{mg} / \mathrm{g}$ during 3.5 months. In the ANOVA test, significant differences were found among the five treatments. On Feb. $06 \mathrm{p}<0.001$. On April $06 \mathrm{p}<0.001$. On June $06 \mathrm{p}<0.001$.

\section{2) NDVI}

The chlorophyll content was measured using remote sensing techniques-NDVI (Figure 2). The relatively higher change was found in the medium treated with spores, even higher than the natural BSC. In the ANOVA test, significant differences were found among the five treatments. On Feb. $06 \mathrm{p}<0.005$. On April $06 \mathrm{p}<0.005$. On June $06 \mathrm{p}<0.005$.

3) Infiltration rates

Infiltration rates were reduced with time in all experiments (Figure 3). The significant change from 9.5 to $4 \mathrm{ml} / \mathrm{min}$ occurred during month 3.5 , in the medium treated with spores. In the ANOVA test, significant differences were found among the four treatments. On Feb. $06 \mathrm{p}<0.005$. On April $06 \mathrm{p}<0.005$. On June $06 \mathrm{p}<$ 0.005 .

4) Protein content

The changes of the protein content as a function of time are presented in Figure 4. As seen in April, three treatments had low concentrations when compared with February. High concentrations were found in June. Two weeks between 23.02.06 to 27.4.06 the Petri dishes were not irrigated due to a technical problem. This might be explaining the drop in NDVI in some of the treatments.

5) Chlorophyll in the field

We ran limited experiments in the field in order to gain assumptions about the growth rate in the field compared to the laboratory experiments. In specific $2 \times$ $1 \mathrm{~m}$ plots (Figure 5), we measured the chlorophyll content by direct extraction from the top most crust layer of the soil surface (Figure 6). Twenty months after the beginning of the experiment showed the importance of sowing spores and propagules on the sandy dunes. As expected, the crust has the highest chlorophyll content with the spores' treatment being significantly higher than the sand treatments, which is statistically similar to the

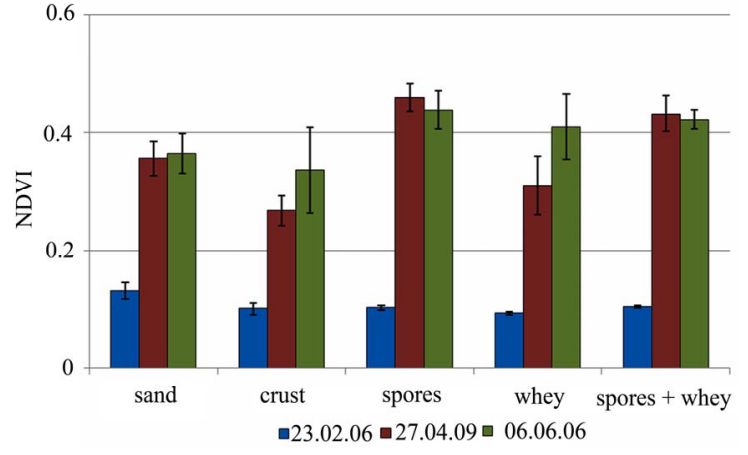

Figure 2. Changes in NDVI value with time. The bars indicate the $\pm \mathrm{SE}$.

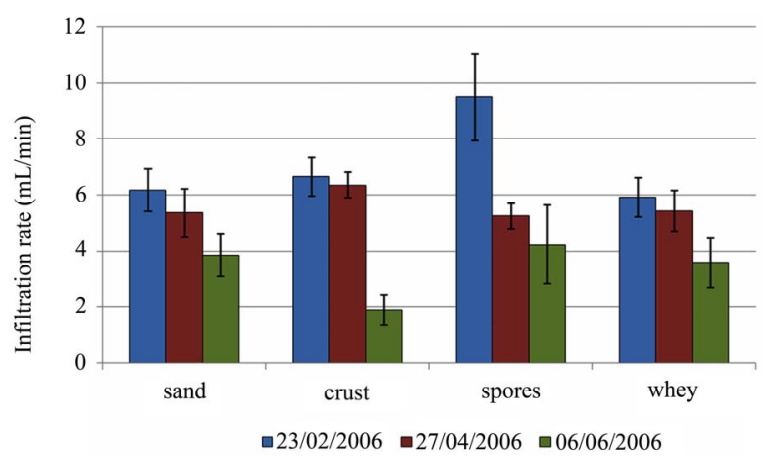

Figure 3. The rate of infiltration in each of the treatments over time. The bars indicate the $\pm \mathrm{SE}$.

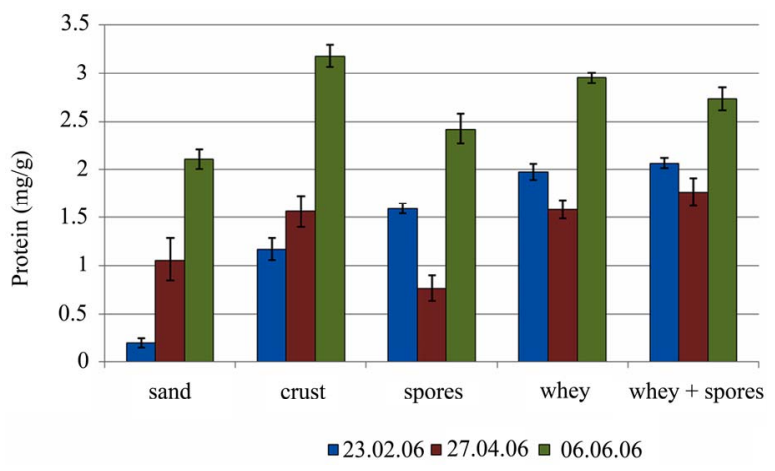

Figure 4. Protein content with time. The bars indicate the $\pm \mathrm{SE}$.

whey treatment.

6) Regression line between dependent variables

NDVI was plotted against infiltration rate and polysaccharide content (Figures 7(a-b)) and polysaccharides was plotted versus infiltration rate (Figure 7(c)).

\section{DISCUSSIONS}

In this study, we examined physical and bio-physiological methods in order to find useful and reliable techniques for monitoring crust development. The findings showed that NDVI is the favored parameter for assessing 


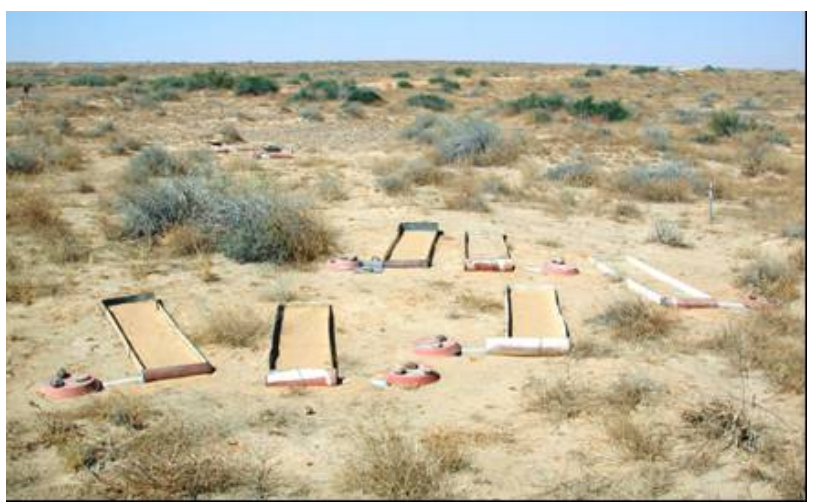

Figure 5. The experiment plots in the field.

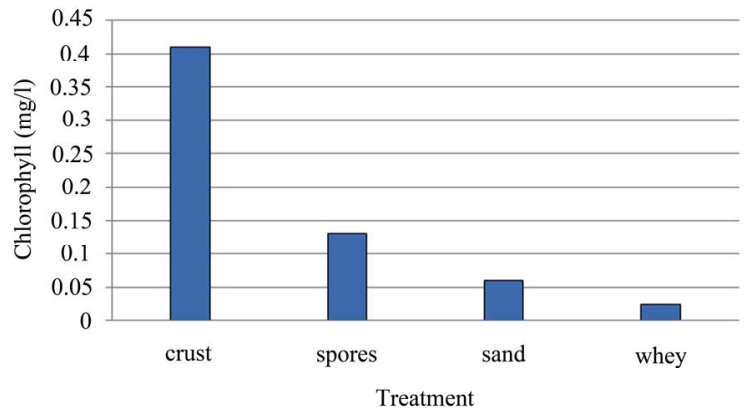

Figure 6. The changes in chlorophyll $\mathrm{a}+\mathrm{b}$ in the field from January 2006 to August 2007.

biological soil-crust growth rate. It is a reliable method for showing the increase of crust development in time, good correlations were found between the variables; infiltration rates and polysaccharide content (as presented in Figure 7). This result concurs with other studies which found that NDVI is well correlated with various vegetation parameters such as green biomass [27] and photosynthetic activity [28]. It has also been found to be useful for various image analyses like crop classification, green coverage and change detection. The reflectance spectra of BSC in semi-arid regions of Australia was studied on a variety of soils [29]. Noticeable differences upon wetting of the BSC were observed using her method. Consequently, it is assumed that a vegetation index, such as NDVI, can serve as a second indicator for recovery of BSC. In [30,31] the authors tested whether the high NDVI values may be caused by the photosynthetic activity of BSCs, which cover most of the soil surfaces in the semi-arid regions of the Negev Desert. They found that the spectral reflectance curves of lower plants can be similar to those of higher ones and their derived NDVI values can be as high as 0.30 units. A high correlation ( $\mathrm{r}$ $=0.79$ ) was reported between NDVI values and chlorophyll content of a wet BSC [6,32].

A similar reliable method was found with infiltration rate measurements. Decreases of the infiltration rate

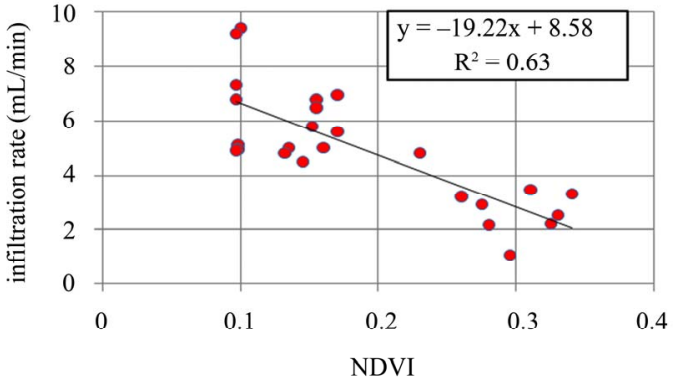

(a)

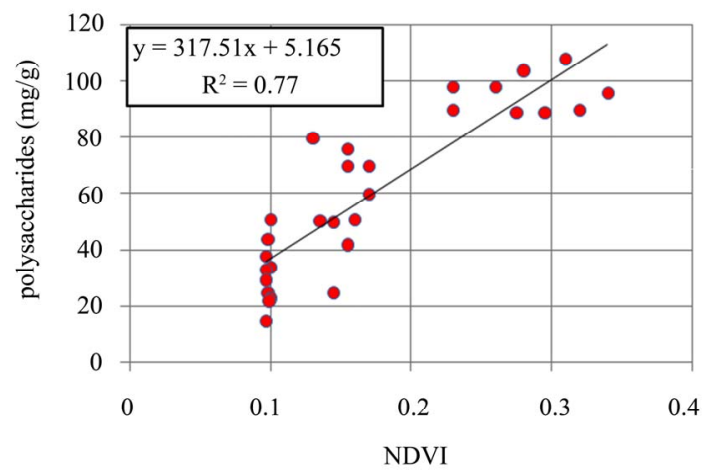

(b)

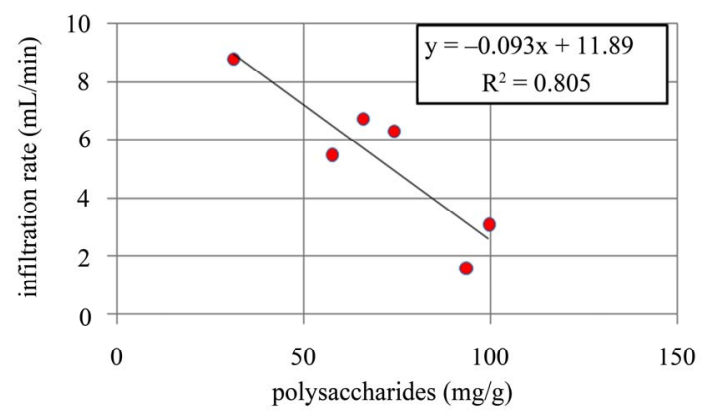

(c)

Figure 7. (a) The correlation between the dependent variables: NDVI vs. infiltration rate. (b) The correlation between the dependent variables: NDVI vs. polysaccharides. (c) The correlation between the dependent variables: polysaccharides vs. infiltration rate.

were shown with crust development over time. Both of the last two analyses used NDVI and infiltration rate measurements, and were nondestructive techniques for the soil surface in the Petri-dishes.

During the growth and the laboratory experiments we used double distilled water (DDW) in order to eliminate any side effect of the photoautotrophic organisms and their exudates that may dissolve within the water and affect the results. For this reason we did not use sterile runoff water. It was reported in the literature that runoff water contain nutrients and organic matter other than propagules [33]. Polysaccharide content in the soil as an indicator of the presence of cyanobacteria microcoleus 
spp. was found to be a good parameter to present the development of the crust (although only 1 gram of soil surface was taken for each replicate). Because protein and organic content are related to two other variables, the standard deviations were relatively too high, in order to identify clear trends in the development of the crusts.

The sandy soil used for the experiments was taken from a depth of $30 \mathrm{~cm}$, under the assumption that no spores and propagules existed at that level. The fact that there were changes in all the parameters in the pure sand treatment used as reference proves that our assumption was wrong.

The next stage of our study focuses on the development of a bio-reactor to grow BSC spores and propagules, as well as to figure out optimum conditions (biological and cost-beneficial). The spores and propagules will be seeded on the target areas in order to shorten the coverage time of the area with BSC (compared to natural growth).

More field experiments are needed to study the applications under field conditions, but our preliminary results showed fast establishment of the spores on sand dune soil at the north-eastern Negev Desert (Yamin plateau). Again, for the point of view of WDS, it must be stated very clearly that the idea of using the BSC is not to replace any other engineered barriers, but to add an additional top layer that increases the soil surface stability by using natural components of the ecosystem in the arid landscape.

\section{CONCLUSIONS}

- NDVI, polysaccharides and infiltration rates are good indicators for showing growth acceleration of the crust;

- Protein and organic content were found to be less indicative.

- The treatments using whey for preliminary crust failed in the lab since cracks were observed, but succeeded in the field experiments.

- In the field, we measured only the chlorophyll content with a time interval of 20 months.

- The methodology of how to accelerate the growth of $\mathrm{BSC}$ was found to be effective.

\section{ACKNOWLEDGEMENTS}

The authors wish to thank Faina Tziperman from Gilat-ARO for her assistance in the laboratory work and Catherine Kelly for reviewing the English.

\section{REFERENCES}

[1] IAEA. (1999) Near Surface Disposal of Radioactive Waste. SR, No. WS-R-1, 29 p.
[2] West, N. E. (1990) Structure and function of microphytic soil crusts in wildland ecosystems of arid to semi-arid regions. Advances in Ecological Research, 20, 179-223. doi:10.1016/S0065-2504(08)60055-0

[3] Johansen, J. R. (1993) Minireview: Cryptogamic crusts of semiarid and arid lands of North America. Journal of Phycology, 29,140-147.

doi:10.1111/j.0022-3646.1993.00140.x

[4] Belnap, J. and Lange, O.L. (2001) Biological soil crusts: Structure, function, and management. Ecological Studies. Springer-Verlage, Berlin, 503.

[5] Zaady, E., Gutterman, Y. and Boeken, B. (1997) The germination effects of cyanobacterial soil crust on mucilaginous seeds of three desert plants: Plantago coronopus, Reboudia pinnata and Carrichtera annua. Plant and Soil, 190, 247-252. doi:10.1023/A:1004269031844

[6] Zaady, E., Karnieli, A. and Shachak, M. (2007) Applying a field spectroscopy technique for assessing successional trends of biological soil crusts in a semi-arid environment. Journal of Arid Environments, 70, 463-477. doi:10.1016/i.jaridenv.2007.01.004

[7] Eldridge, D.J. and Leys, J.F. (2003) Exploring some relationships between biological soil crusts, soil aggregation and wind erosion. Journal of Arid Environments, 53, 457-466. doi:10.1006/jare.2002.1068

[8] Hua, C., Liua, Y., Paulsenb, B.S., Petersenc, D. and Klavenessd, D. (2003) Extracellular carbohydrate polymers from five desert soil algae with different cohesion in the stabilization of fine sand grain. Carbohydrate Polymers, 54, 33-42. doi:10.1016/S0144-8617(03)00135-8

[9] De-Philipis, R., Margheri, M. C., Pelosi, E. and Ventura, S. (1993) Exopolysacchride production by a unicellular cyanobacterium isolated from a hypersaline habitat. Journal of Applied Phycology, 5, 387-394. doi:10.1007/BF02182731

[10] Belnap, J. and Gillette, D.A. (1998) Vulnerability of desert biological soil crusts to wind erosion: The influences of crust development, soil texture, and disturbance. Journal of Arid Environments, 39, 133-142. doi:10.1006/jare.1998.0388

[11] Belnap, J., Phillips, S.L., Witwickia, D.L. and Miller, M.E. (2004) Visually assessing the level of development and soil surface stability of cyanobacterially dominated biological soil crusts. Journal of Arid Environments, 72, 1257-1264. doi:10.1016/j.jaridenv.2008.02.019

[12] Yair, A. (1990) Runoff generation in a sandy area-the Nizzana sands, Western Negev. Israel Earth Surface Proceedings, 15, 597-609.

[13] Verrecchia E, Yair, A., Kidron, G.J. and Verrecchia, K. (1995) Physical properties of the psammophile cryptogamic crust and their consequences to the water regime of sandy soils, north-western Negev Desert, Israel. Journal of Arid Environments, 29,427-437. doi:10.1016/S0140-1963(95)80015-8

[14] Shachak, M., Sachs, M. and Moshe, I. (1998) Ecosystem management of desertied shrublands in Israel. Ecosystems, 1,475-483. doi:10.1007/s100219900043

[15] Belnap, J. (2006) The potential roles of biological soil crusts in dryland hydrologic cycles. Hydrology Processes, 20, 3159-3178. doi:10.1002/hyp.6325

[16] Eldridge, D.J., Zaady, E. and Shachak, M. (2002) Microphytic crusts, shrub patches and water harvesting in the Negev desert: The shikim system. Landscape Ecol- 
ogy, 17, 587-597. doi:10.1023/A:1021575503284

[17] Eldridge, D.J., Zaady, E. and Shachak, M. (2000) Infiltration through three contrasting biological soil crusts in patterned landscapes in the Negev, Israel. Catena, 40, 323-336. doi:10.1016/S0341-8162(00)00082-5

[18] Anderson, D.C., Harper, K.T. and Rushforth, S.R. (1982) Recovery of cryptogamic soil crusts from grazing on Utah winter ranges. Journal of Range Management, 35, 355-359. doi: $10.2307 / 3898317$

[19] Dische, Z. (1962) General color reactions. Methods Carbohydrate Chemistry, 1, 477-479.

[20] Lowry, O.H., Rosebrough, N.J., Farr, A.L. and Randall, R.J. (1951) Protein measurment with the folin-phenol reagent. Journal of Biology and Chemistry, 193, 265-275.

[21] Lichtenthaler, H.K. and Wellburn, A.R. (1983) Determinations of total carotenoids and chlorophyll $\mathrm{a}$ and $\mathrm{b}$ of leaf extracts in different solvents. Biochemistry Society Transactions, 603, 591-592.

[22] Ben-Dor, E. and Banin, A. (1989) Determination of organic matter content in arid-zone soils using a simple "losson-ignition" method. Communications in Soil Science and Plant Analysis, 20, 1675-1696. doi:10.1080/00103628909368175

[23] Bannari, A., Morin, D., Bonn, F. and Huete, A.R. (1995) A review of vegetation indices. Remote Sensing Review, 13, 95-120.

[24] Rouse, J.W., Haas, R.H., Schell, J.A., Deering, D.W. and Harlan, J.C. (1974) Monitoring the Vernal Advancements and Retrogradation (Greenwave Effect) of Natural Vegetation. NASA/GSFC Final Report, NASA, Greenbelt.

[25] Jelen, P. (1992) Whey: Composition, properties, processing and uses in encyclopedia of food science and technology. In: Hui, Y. H., Ed., Encyclopedia of Food Science and Technology, John Wiley \& Sons, New York, 2835-
2845.

[26] Sokal R.R. and Rohlf, F.J. (1995) Biometry (3rd Edition). Freeman, W. H. and Company, San Francisco.

[27] Tucker, J.C. (1979) Red and photographic infrared linear combination for monitoring vegetation. Remote Sensing of Environment, 8, 127-150. doi:10.1016/0034-4257(79)90013-0

[28] Sellers, P.J. (1985) Canopy reflectance, photosynthesis and transpiration. International Journal of Remote Sensing, 6, 1335-1372. doi:10.1080/01431168508948283

[29] O’Neill, A.L. (1994) Reflectance spectra of microphytic soil crusts in semi-arid Australia. International Journal of Remote Sensing, 15, 675-681. doi:10.1080/01431169408954106

[30] Karnieli, A. and Tsoar, H. (1995) Satellite spectral reflectance of biogenic crust developed on desert dune sand along the Israel-Egypt border. International Journal of Remote Sensing, 16, 369-374. doi:10.1080/01431169508954403

[31] Karnieli, A., Shachak, M., Tsoar, H., Zaady, E., Kaufman, Y., Danin, A. and Porter, W. (1996) The effect of microphytes on the specteral reflectance of vegetation in semiarid regions. Remote Sensing of Environment, 57, 88-96. doi:10.1016/0034-4257(95)00209-X

[32] Karnieli, A., Kokaly, R., West, N.E. and Clark, R.N., (2001) Remote sensing of biological soil crusts. In: Belnap, J. and Lange, O.L. Eds., Biological Soil Crusts: Structure, Function and Management, Springer-Verlag, Berlin, 431- 455.

[33] Zaady, E., Levacov, R. and Shachak, M. (2004) Application of the herbicide, Simazine, and its effect on soil surface parameters and vegetation in a patchy desert landscape. Arid Land Research and Management, 18, 397410. doi:10.1080/15324980490497483 